\title{
The Contribution of Yield Components to the Achievement of Production in some Winter Wheat Genotypes
}

\author{
Ionuț RACZ ${ }^{1,2}$, Ioan HAȘ ${ }^{1,2}$, Vasile MOLDOVAN ${ }^{2}$, Rozalia KADAR², Adrian CECLAN ${ }^{2}$ \\ ${ }^{1}$ University of Agricultural Science and Veterinary Medicine - Cluj Napoca \\ ${ }^{2}$ Agricultural Research and Development Station- Turda \\ *Corresponding author: racz_ionut@yahoo.com \\ Bulletin USAMV series Agriculture 72(2)/2015 \\ Print ISSN 1843-5246; Electronic ISSN 1843-5386 \\ DOI 10.15835/buasvmcn-agr: 11733
}

\begin{abstract}
The grain yield is the result of a complex interaction of many factors, which can be more or less influenced by environmental conditions. Number of grain per spike, weight of grain per spike and thousand kernel weight are the main components of the yield. The reaction of these components to variations of climatic conditions or other inputs can be different, according to genotypes. In our research the climatic conditions have determined a large variation of this components, especially caused by favorable and unfavorable conditions. The greatest contribution on grain yield was manifested by weight of grain per spike (correlation coefficient 0.62 in 2012, and 0.70 in 2013 at basic fertilization; 0,76 in the second experimental year and 0.62 in third year at additional fertilization), followed by number of grain per spike (correlation coefficient: 0.45 in 2012 and 0.53 in 2013 at basic fertilization, and 0,49 in second experimental year at additional fertilization).
\end{abstract}

Keywords: environment, genotypes, yield, technological inputs, wheat.

\section{INTRODUCTION}

Considering the fact that the yield is the result of many factors, it is very important to know all mechanisms that determine grain yield of wheat (Williams, 1971-1972). Every wheat genotypes have different reaction to the existing environmental conditions or agronomic inputs, therefore, to maximize the production it is appropiate to know some aspects regarding the influential factors affecting the yield components (Adhikary and all., 2009, Lihua and all., 2013) and finally under grain yield. As it is known the main yield components which determine the yield are the number of grain per spike, the weight of grain per spike as soon as thousand kernel weight. The environmental conditions can have a high influence on the expressiveness of these characters.
Wheat grain yield capacity is mainly conditioned by intern factors (related to genotype) and by influence factors (related to environment) (Silva et all., 2014). Grain yield represent the result of the interaction between yield potential of genotype and the influence of environmental conditions, alongside the genotype capacity to exploit husbandry factors.

Grain yield is one of most complex characters, which contribute to the achievement of a lot of elements and traits, which in turn have a wellestablished genetic determinism that can be more or less influenced by environmental conditions (Thorne and Wood, 1987).

The complexity of this character comes from the multitude of factors involved in its production, and shortcomings of any of these factors have a 
direct effect on the grain production (Oventry et all., 2011).

The aim of this paper was to identify the influence of genotype $\mathrm{X}$ environment (including technological inputs) interaction in the achievement of wheat yield at Agricultural Research \& Development Station Turda (ARDS Turda).

\section{MATERIALS AND METHODS}

The experiments were conducted over three years, from 2011 to 2013 at ARDS Turda. The climatic conditions are characterized by a high (heavy) rainfall and temperatures favourable for winter wheat crop. The biologic material used in this study is quite varied, consisting of 25 winter wheat varieties of domestic and foreign origin
(Table 1). The obtained data were processed by analysis of variance, some usually statistics parameters and regression multiple analysis (grain yield and dependent variable).

\section{RESULTS AND DISCUSSION}

Interpretation of the analysis of variance (ANOVA), which is presented in table 2, it can be observed, besides of a very significant influence of A factor (environmental conditions), the most important achievement is to realize the grain yield over the three experimental years had also fertilizer application (B factor).

Thus, testing the significance of the calculated values using $\mathrm{F}$ test, showed the existence of some very significant differences within the graduation

Tab. 1. Origin of the winter wheat cultivars tested in the yield trials at ARDS Turda

\begin{tabular}{ccc}
\hline Country & \multicolumn{1}{c}{ Place of origin } & Cultivars \\
\hline \multirow{3}{*}{ Romania } & Turda & Apullum ; Arieșan; Dumbrava; T 96-97; T 67-02; Andrada \\
\cline { 2 - 3 } & Fundulea & Boema; Delabrad; Dropia; Faur; Gruia; \\
\cline { 2 - 3 } & Lovrin & Lovrin 34 \\
\cline { 2 - 3 } & Albota & Trivale \\
\hline \multirow{3}{*}{ Hungary } & Szeged & GK Othalom; GK Kalasz \\
\cline { 2 - 3 } & Martonvásár & MV Martina; MV Palotas; MV Mandolin; MV Mariska; Maty; MV 06-02 \\
\cline { 2 - 3 } & Kiskun & Serina \\
\hline Austria & & Josef \\
\hline France & Limagrain & Renan \\
\hline Russia & Krasnodar & Bezostaia \\
\hline
\end{tabular}

Tab. 2. ANOVA test for yield at winter wheat in polifactorial experience $(3$ years $x 2$ level of fertilization x 25 variants ) at ARDS Turda, 2010-2013

\begin{tabular}{ccccc}
\hline Source of variance & Sum of square (SS) & Degree of freedom (DF) & Mean square $\left(\mathrm{s}^{2}\right)$ & Test F \\
\hline A ( year) & 863.287 & 2 & 431.644 & $582.467^{* * *}$ \\
\hline B (fertilization) & 157.011 & 1 & 157.011 & $1047.047^{* * *}$ \\
\hline A x B & 4.813 & 2 & 2.407 & $16.049^{* *}$ \\
\hline C (variety) & 39.558 & 24 & 1.648 & $18.146^{* *}$ \\
\hline A x C & 32.213 & 48 & 0.671 & $7.388^{* *}$ \\
\hline B x C & 4.215 & 24 & 0.176 & $1.933^{* *}$ \\
\hline A x B x C & 4.875 & 48 & 0.102 & 1.118 \\
\hline Other types of intreactions & 31.584 & 300 & - & - \\
\hline Error A & 2.964 & 4 & 0.741 & - \\
\hline Error B & 0.900 & 6 & 0.150 & - \\
\hline Error C & 26.160 & 288 & 0.091 & - \\
\hline Total & 1137.556 & 449 & - & - \\
\hline
\end{tabular}


of each factor and also between factors' interactions.

Additional fertilization play an important role under grain yield, determining an increase of more than $1000 \mathrm{~kg} / \mathrm{ha}$ as compared to the basic fertilization in the three experimental years (table 3 ). The differences of grain yield between the three years are caused firstly by the environmental condition which can be appreciated that was very favorable in 2013, favorable in 2012 and unfavorable in 2011 for the winter wheat crop, according to recorded data at meteorological station Turda.

Beside the yield gain, additional fertilizations contribute to the increasing of grain yield stability, providing better adaptability plants to the varying climatic conditions. The productions variation recorded was quite large, both between genotypes and experimental years especially in the first experimental year and second or third year. In favorable environmental conditions (2012 or 2013) the large yield variation suggests the different capacity of genotypes to capitalize the optimal conditions.

Regarding the number of grain per spike, the analyses of variance for this character (table 4) show a very significant influence of A factor and $C$ factor, and a distinct significant influence of $B$ factor alongside double-interactions between factors, respectively triple interactions.

The statistical parameters for number of grain per spike (table 5) highlights that the additional

Tabl. 3. Statistical parameters for grain yield at 25 winter wheat varieties (Turda, 2010-2013)

\begin{tabular}{|c|c|c|c|c|c|c|c|c|}
\hline \multirow{4}{*}{$\begin{array}{c}\text { Statistic } \\
\text { parameters }\end{array}$} & \multicolumn{8}{|c|}{ Grain yield (kg/ha) } \\
\hline & \multicolumn{2}{|c|}{2011} & \multicolumn{2}{|r|}{2012} & \multicolumn{2}{|r|}{2013} & \multicolumn{2}{|r|}{ Mean } \\
\hline & \multicolumn{8}{|c|}{ Fertilization } \\
\hline & basic & additional & Basic & additional & basic & Additional & basic & additional \\
\hline Average & 2654 & 4003 & 5117 & 6311 & 6182 & 7103 & 4651 & 5806 \\
\hline Standard deviation & 307.5 & 340.9 & 471.9 & 503.4 & 413.5 & 527.5 & 299.4 & 341.5 \\
\hline Min & 1942 & 3309 & 3977 & 4903 & 5113 & 5812 & 4158 & 5006 \\
\hline Max & 3201 & 4575 & 6169 & 7210 & 6812 & 8101 & 5175 & 6503 \\
\hline $\begin{array}{c}\text { Coefficient of variation } \\
(\mathrm{s} \%)\end{array}$ & 11.59 & 8.51 & 9.22 & 7.97 & 6.96 & 7.43 & 6.44 & 5.88 \\
\hline
\end{tabular}

Tab. 4. ANOVA test for number of grain/spike at winter wheat in polifactorial experience (3 years x 2 level of fertilization x 25 variants) at ARDS Turda, 2010-2013

\begin{tabular}{ccccc}
\hline Source of variance & $\begin{array}{c}\text { Sum of square } \\
(\mathrm{SS})\end{array}$ & $\begin{array}{c}\text { Degree of } \\
\text { freedom } \\
(\mathrm{DF})\end{array}$ & $\begin{array}{c}\text { Mean square } \\
\left(\mathrm{s}^{2}\right)\end{array}$ & Test F \\
\hline A ( year) & 10625,400 & 2 & 5312,701 & $299,462^{* * *}$ \\
\hline B (fertilization) & 181,667 & 1 & 181,667 & $30,241^{* *}$ \\
\hline A x B & 282,668 & 2 & 141,334 & $23,527^{* *}$ \\
\hline C (variety) & 3158,337 & 24 & 131,597 & $13,847^{* * *}$ \\
\hline A x C & 1962,738 & 48 & 40,890 & $4,303^{* *}$ \\
\hline B x C & 423,446 & 24 & 17,644 & $1,856^{* *}$ \\
\hline A x B x C & 841,053 & 48 & 17,521 & $1,844^{* *}$ \\
\hline Other types of intreactions & 2857,962 & 300 & - & - \\
\hline Error A & 70,963 & 4 & 17,741 & - \\
\hline Error B & 36,044 & 6 & 6,007 & - \\
\hline Error C & 2737,102 & 288 & 9,504 & - \\
\hline Total & 20333,270 & 449 & - & - \\
\hline
\end{tabular}


fertilization determines generally an increase average of the number of grain per spike, excepting the third experimental year when the nutritional support had a rather negative influence. However, the additional fertilization had generated lower values of the coefficient of variation as compared with the basic fertilization. The values variation for number of grain per spike (lower values in 2011 compared with 2012 or 2013) confirm that the environmental conditions had an important influence on the genetic determinism of this characters.

ANOVA for weightofgrain perspikeas ayielding character can be observed in table 6 . The values of $\mathrm{F}$ test for this character suggested that the weight of grain per spike is a very vulnerable element of productivity, being influenced very significant by all tree studied factors and by interaction between year and fertilization (A $\mathrm{x}$ B), and a distinct significant influence by double interaction: $\mathrm{A} \times \mathrm{C}$ and $\mathrm{B} \times \mathrm{C}$, abreast triple-interaction $(\mathrm{A} \times \mathrm{B} \times \mathrm{C})$. The increased value of $A$ factor $\left(895,586^{* * *}\right)$ suggests increased contribution of climatic conditions to realize this character.

From table 7 can be observed the influences of climatic conditions on weight of grain per spike. Being an influential character - weight of grain per spike, the values of this character were quite variable. The unfavorable conditions from 2011 determined a range of weight of grain per spike between $0,982 \mathrm{~g}$ at basic fertilization to $1,131 \mathrm{~g}$ to additional fertilization, while in very favorable conditions (2013) the range of studied character was $1,570 \mathrm{~g}$ at basic fertilization and 1,560 g to additional fertilization. The increased value of basic fertilization compared with additional

Tab. 5. Statistical parameters for number of grain per spike at 25 winter wheat varieties (Turda, 20102013)

\begin{tabular}{|c|c|c|c|c|c|c|c|c|c|}
\hline \multirow{4}{*}{\multicolumn{2}{|c|}{ Statistics }} & \multicolumn{8}{|c|}{ Number of grain/spike } \\
\hline & & \multicolumn{2}{|c|}{2011} & \multicolumn{2}{|c|}{2012} & \multicolumn{2}{|c|}{2013} & \multicolumn{2}{|c|}{ Mean } \\
\hline & & \multicolumn{8}{|c|}{ Fertilization } \\
\hline & & basic & additional & Basic & additional & basic & additional & basic & additional \\
\hline & Average & 23.08 & 26.16 & 31.67 & 34.26 & 34.28 & 33.71 & 29.68 & 31.37 \\
\hline Star & dard deviation & 2.13 & 2.01 & 2.86 & 3.09 & 3.59 & 3.40 & 1.79 & 2.04 \\
\hline \multirow{2}{*}{ Range } & Min & 19.20 & 22.68 & 26.67 & 27.53 & 25.41 & 25.25 & 26.22 & 27,24 \\
\hline & Max & 26.95 & 30.47 & 36.95 & 40.87 & 40.55 & 41.33 & 33.74 & 35,47 \\
\hline Coefficie & nt of variation (s\%) & 9.21 & 7.67 & 9.02 & 9.02 & 10.47 & 10.09 & 6.03 & 6.52 \\
\hline
\end{tabular}

Tab. 6. ANOVA test for weight of grain/spike at winter wheat in polifactorial experience (3 years $\mathrm{x} 2$ level of fertilization x 25 variants) at ARDS Turda, 2010-2013

\begin{tabular}{ccccc}
\hline Source of variance & Sum of square (SS) & Degree of freedom (DF) & Mean square $\left(\mathrm{s}^{2}\right)$ & Test F \\
\hline A (year) & 13.773 & 2 & 6.887 & $895.586^{* * *}$ \\
\hline B (fertilization) & 0.925 & 1 & 0.925 & $229.931^{* * *}$ \\
\hline A x B & 0.730 & 2 & 0.365 & $90.713^{* * *}$ \\
\hline C (variety) & 3.845 & 24 & 0.160 & $26.556^{* * *}$ \\
\hline A x C & 4.682 & 48 & 0.098 & $16.167^{* *}$ \\
\hline B x C & 0.697 & 24 & 0.029 & $4.813^{* *}$ \\
\hline A x B x C & 1.379 & 48 & 0.029 & $4.761^{* *}$ \\
\hline Other types of interactions & 1.802 & 300 & 0.006 & - \\
\hline Error A & 0.031 & 4 & 0.008 & - \\
\hline Error B & 0.024 & 6 & 0.004 & - \\
\hline Error C & 1.738 & 288 & 0.006 & - \\
\hline Total & 27.832 & 449 & - & - \\
\hline
\end{tabular}


fertilization in the third experimental year can be explained by the fact that by additional fertilization the plant density was higher. Likewise for the other characters studied, additional fertilization increased the stability of weight of grain per spike.

It is know that the thousand kernel weight has a high genetic determinism. That fact was confirmed through our experiments too. If we analyze the date of ANOVA from table 8, it can be observed the importance of $\mathrm{C}$ factor (genotype) under the expressiveness of thousand kernel weight character. A very significant influence is also manifested by double-interaction of $\mathrm{A} x$ $C$ factors (year $\mathrm{x}$ variety) close abroad A factor (environment condition of year). B factor and the other interaction have also a distinct significance on thousand kernel weight.
In the three experimental years the variation of thousand kernel weight character was low enough (table 9). Besides the increased stability of thousand kernel weight $(5,08$ to additional fertilization compared with 5,31 to basic fertilization) the additional fertilization caused a slight increase of values for studied character (from $44,18 \mathrm{~g}$ to $45,01 \mathrm{~g}$ to extra fertilization). It can be noticed the small influence between years environment conditions compared with influence of those under the number of grain per spike or the weightofgrain per spike. For abetter understanding of mechanism and interaction which participate to grain yield formation we proceed to calculate the correlations between grain yield and the main traits of the plant which have high influence on grain yield (table 10). In a year with a modest

Tab. 7. Statistical parameters for grain weight per spike at 25 winter wheat varieties ( Turda, 20102013)

\begin{tabular}{|c|c|c|c|c|c|c|c|c|c|}
\hline & & \multicolumn{8}{|c|}{ Grain weight per spike (g) } \\
\hline \multirow{3}{*}{\multicolumn{2}{|c|}{ Statistics }} & \multicolumn{2}{|c|}{2011} & \multicolumn{2}{|c|}{2012} & \multicolumn{2}{|c|}{2013} & \multicolumn{2}{|c|}{ Mean } \\
\hline & & \multicolumn{8}{|c|}{ Fertilization } \\
\hline & & basic & additional & basic & additional & basic & additional & basic & additional \\
\hline Ave & & 0.982 & 1.131 & 1.392 & 1.550 & 1.570 & 1.560 & 1.315 & 1.414 \\
\hline Standard & eviation & 0.100 & 0.090 & 0.128 & 0.122 & 0.175 & 0.155 & 0.076 & 0.077 \\
\hline \multirow{2}{*}{ Range } & Min & 0.751 & 0.938 & 1.155 & 1.305 & 1.158 & 1.393 & 1.172 & 1.286 \\
\hline & Max & 1.170 & 1.339 & 1.604 & 1.794 & 2.032 & 1.967 & 1.497 & 1.610 \\
\hline \multicolumn{2}{|c|}{$\begin{array}{c}\text { Coefficient of } \\
\text { variation }(\mathrm{s} \%)\end{array}$} & 10.14 & 7.92 & 9.16 & 7.88 & 11.14 & 9.91 & 5.75 & 5.45 \\
\hline
\end{tabular}

Tab. 8. ANOVA test for thousand kernel weight ( TKW) at winter wheat in polifactorial experience with 3 factors in 3 replications (3 years x 2 level of fertilization x 25 variants) at ARDS Turda, 2010-2013

\begin{tabular}{ccccc}
\hline Source of variance & Sum of square (SS) & Degree of freedom (DF) & Mean square $\left(\mathrm{s}^{2}\right)$ & Test F \\
\hline A (year) & 715,483 & 2 & 357,741 & $797,245^{* * *}$ \\
\hline B (fertilization) & 63,169 & 1 & 63,169 & $32,989^{* *}$ \\
\hline A x B & 47,831 & 2 & 23,915 & $12,489^{* *}$ \\
\hline C (variety) & 1960,962 & 24 & 81,707 & $66,027^{* * *}$ \\
\hline A x C & 1513,016 & 48 & 31,521 & $25,472^{* * *}$ \\
\hline B x C & 151,673 & 24 & 6,320 & $5,107^{* *}$ \\
\hline A x B x C & 566,171 & 48 & 11,795 & $9,532^{* *}$ \\
\hline Other types of intreactions & 375,887 & 300 & 1,253 & - \\
\hline Error A & 1,795 & 4 & 0,449 & - \\
\hline Error B & 11,489 & 6 & 1,915 & - \\
\hline Error C & 356,392 & 288 & 1,237 & - \\
\hline Total & 5394,190 & 449 & - & - \\
\hline
\end{tabular}


yield (2011) the significant correlations appear only with specific weight $\left(0,44^{*}\right)$ on the basic fertilization. Also, on additional fertilization has been observed a direct correlation between the spike density and grain yield $\left(0,49^{*}\right)$ respectively the negative correlation between grain yield and wet gluten content $(-0,49 *)$. Most correlations (8) appear in second year of experiment: positive correlation between grain yield and number of grain per spike $\left(0,45^{*}\right.$ to basic fertilization and $0,49 *$ to additional fertilization), grain yield and grain weight per spike $\left(0,62^{* *}\right.$ to basic fertilization and $0,76^{* *}$ to additional fertilization), grain yield and plant height $\left(0,41^{*}\right.$ to basic fertilization and $0,45^{*}$ to additional fertilization).
Two negative correlations were observed between grain yield and wet gluten content ($0,52^{* *}$ ) to basic fertilization and one of grain yield and protein content $\left(-0,61^{* *}\right)$ to additional fertilization.

In the last experimental year (2013) there has appeared a positive correlation between grain yield and the number of grain per spike, grain yield and grain weight per spike, grain yield and spike density, and a negatively correlation between grain yield and protein content (basic fertilization). In the same year for additional fertilization we have a positive correlation between grain yield and grain weight per spike, grain yield and spike density, and a strongly negative correlation between grain yield and protein content.

Tab. 9. Statistical parameters for thousand kernel weight at 25 winter wheat varieties ( Turda, 20102013)

\begin{tabular}{|c|c|c|c|c|c|c|c|c|c|}
\hline \multirow{4}{*}{\multicolumn{2}{|c|}{ Statistics }} & \multicolumn{8}{|c|}{ Thousand kernel weight (g) } \\
\hline & & \multicolumn{2}{|c|}{2011} & \multicolumn{2}{|c|}{2012} & \multicolumn{2}{|c|}{2013} & \multicolumn{2}{|c|}{ Mean } \\
\hline & & \multicolumn{8}{|c|}{ Fertilization } \\
\hline & & Basic & additional & basic & additional & basic & additional & Basic & additional \\
\hline & & 42.57 & 43.28 & 44.04 & 45.36 & 45.92 & 46.39 & 44.18 & 45.01 \\
\hline Stand & iation & 2.20 & 2.05 & 2.79 & 2.76 & 3.86 & 3.56 & 2.35 & 2.29 \\
\hline \multirow{2}{*}{ Range } & Min & 38.44 & 39.20 & 35.82 & 37.77 & 35.97 & 37.94 & 37.17 & 38.30 \\
\hline & Max & 46.47 & 46.93 & 48.40 & 49.72 & 56.17 & 56.75 & 48.58 & 49.77 \\
\hline Coefficient & ation (s\%) & 5.17 & 4.73 & 6.33 & 6.08 & 8.41 & 7.68 & 5.31 & 5.08 \\
\hline
\end{tabular}

Tab. 10. Correlation coefficient $(\mathrm{r}$ ) between different morpho-physiological and quality traits at winter wheat on two levels of fertilization (Turda, 2011-2013)

\begin{tabular}{|c|c|c|c|c|c|c|}
\hline \multirow{4}{*}{ Correlated character } & \multicolumn{6}{|c|}{ Grain yield (kg/ha) } \\
\hline & \multicolumn{2}{|c|}{2011} & \multicolumn{2}{|c|}{2012} & \multicolumn{2}{|c|}{2013} \\
\hline & \multicolumn{6}{|c|}{ Fertilization } \\
\hline & basic & additional & basic & additional & basic & Additional \\
\hline $\begin{array}{l}\text { Number of grain } \\
\text { per spike }\end{array}$ & 0.32 & 0.11 & $\underline{0.45^{*}}$ & $\underline{0.49 *}$ & $\underline{0.53^{* *}}$ & 0.35 \\
\hline Grain weight/spike(g) & 0.12 & 0.20 & $\underline{0.62^{* *}}$ & $\underline{0.76^{* *}}$ & $\underline{0.70^{* *}}$ & $\underline{0.62^{* *}}$ \\
\hline TKW (g) & 0.22 & 0.17 & 0.24 & 0.22 & 0.23 & 0.29 \\
\hline Specific weight(kg/hl) & $\underline{0.44 *}$ & 0.28 & -0.18 & 0.36 & 0.02 & 0.11 \\
\hline Plant height $(\mathrm{cm})$ & 0.19 & -0.03 & $\underline{0.41^{*}}$ & $\underline{0.45^{*}}$ & 0.20 & 0.25 \\
\hline Spike density $/ \mathrm{m}^{2}$ & 0.28 & $\underline{0.49 *}$ & -0.19 & -0.05 & $\underline{0.63 * *}$ & $\underline{0.56^{* *}}$ \\
\hline Protein content(\%) & -0.27 & -0.23 & -0.31 & $\underline{-0.61 * *}$ & $-0.55^{* *}$ & $\underline{-0.72 * *}$ \\
\hline Wet gluten content $(\%)$ & -0.17 & $-0.49^{*}$ & $\underline{-0.52^{* *}}$ & -0.39 & -0.22 & -0.38 \\
\hline
\end{tabular}




\section{CONCLUSION}

Production of small grain cereals, as well as any crops, is the result of complex genotypeenvironment interactions, leading to a high degree of variability. Interventions with elements of technology can mitigate the unpredictable influence of environmental factors.

Grain yield is determined by the number of grains per spike, weight of grain per spike, and thousand kernel weight, elements which have more or less contribution in grain production, depending on the environment conditions and on the applied technological factors.

Acknowledgements. Thispaperwas published under the frame of European Social Fund, Human Resources Development Operational Programme 2007-2013, project no. POSDRU/159/1.5/S/ 132765.

\section{REFERENCES}

1. Adhikary SK, Alam MZ, Paul NK (2009). Variation of grain growth of wheat cultivars, Bangladesh J. Agril. Res. 34(3): 351-359.

2. Lihua Lv, Yanrong Yao, Lihua Zhang, Zhiqiang Dong, Xiuling Jia, Shuangbo Liang, and Junjie J (2013). Winter wheat grain yield and its components in the North China Plain: irrigation management, cultivation, and climate, Chilean J. Agric. Res., 73:3.

3. Oventry, D. R.; Gupta, R. K.; Poswal, R. S.; Chhokar, R. S.; Sharma, R. K.; Yadav, V. K.; Gill SC, Mentha A, Kleemann SGL, Bonamano A, Cummins JA (2011). Wheat quality and productivity as affected by varieties and sowing time in Haryana, India., Field Crops Research, 123:214-225.

4. Silva RR, Benin G, de Almeida JL, de Batista Fonseca IC, Zucareli C (2014). Grain yield and baking quality of wheat under different sowing dates, Acta Sci. Agron, 36:2.

5. Thorne GN, Wood DW (1987). Effects of radiation and temperature on tiller survival, grain number and grain yield in winter wheat, Annals of Botany 59:413-426.

6. Williams GDV (1971-1972). Geographical variations in yield-weather relationships over a large wheat growing region, Agricultural Meteorology 9:65-283. 